\title{
Government Efforts to Raise Awareness of Palembang City Residents to the Culture of Participation
}

\author{
Heni Widia Nengsi and Karim Suryadi \\ Sekolah Pascasarjana \\ Universitas Pendidikan Indonesia \\ Bandung, Indonesia \\ Heniwidianengsi@rocketmail.com
}

\begin{abstract}
This research is important to do because considering at the present time, the participation rate of citizens in the city of Palembang is quite low. This is evidenced by the decline in the level of citizen participation in the elections in 2013. Therefore, this study is deemed necessary to do because based on several reasons, First, Undang-Undang Dasar 1945 article 28, every citizen has the right to independence, assembly and assembly, issuing thoughts with oral and written and so forth is established by law. Secondly, as a democratic country, the status of a citizen is essentially a holder of sovereignty or power in any governmental decision-making. Third, the importance of participatory skills in democratic countries aims to develop democratic education that develops three main functions, one of which is to encourage a culture of citizen participation. The approach in this research using qualitative approach, with case study method. The sample was obtained by using purposive sampling technique with research informant is Head of Public Relations, Head of Communication and Information of Palembang City and citizens of Palembang City. Validity test conducted in this research is credibility test, transfer-ability test, dependability test, and confirm-ability test. Data collection techniques used are, interviews, observation, and documentation. Data analysis techniques used are data reduction, data presentation, and data verification. The results of this study, it is known that efforts to increase the awareness of Palembang city residents to participatory culture that was done by the government of Palembang city to capture increased public participation, through social media as a place of community in channeling aspirations.
\end{abstract}

Keywords—citizen; political participation; social media

\section{INTRODUCTION}

Research on awareness of citizenship in the aggregate of citizens' interests is deemed necessary at least for several reasons. First, Undang- Undang Dasar 1945 of article 28, every citizen has the right to freedom, assembly and assembly, to issue thoughts with oral and written and so forth constituted by law [1].

Secondly, as a democratic country, the status of a citizen is essentially a holder of sovereignty or power in any governmental decision-making. This theory of people's sovereignty as the forerunner of the teachings of democracy [2] [3].

Third, the importance of participatory skills in democratic countries aims to develop democratic education that develops three main functions, one of which is to encourage civic participation. As Aristotle has described in his Politics [2]. Aristotle argued, "If freedom and equality as according to the opinion of one can be obtained primarily in a democracy, then that freedom and equality will be attainable if everyone without exception participates fully in the government." [4] In other words, the ideals of democracy can be manifestly realized when every citizen can participate in his government [5].

According to the Election Commission (KPU) of the city of Palembang, Palembang City has conducted direct election of Regional Head and Deputy Regional Head (Pemilukada) in 2008 and last year 2013. In 2008, voter participation rate was $67 \%$ using the right to vote. Whereas in 2013 , the number of voters who exercised their voting rights ranged from $65 \%$ [6].

Based on the above description the researcher is interested to examine How the government efforts to increase awareness of Palembang city residents to the culture of participation?

\section{METHODOLOGY}

Approach in this research use qualitative approach with case study method. With the number of informants as many as seven people consisting of one person Head of Public Relations of Palembang City, one person Head of Communication and Information City of Palembang, and Citizens of Palembang City. The location of this research is Palembang City. For data collection techniques, researchers use documentation, interview and observation techniques. Then test the validity of data used in this study is the test credibility, transfer-ability test, dependability test, and confirm-ability test. Further data analysis techniques used are qualitative data analysis techniques that include data reduction, data presentation and conclusion. 


\section{RESEARCH RESULT AND DISCUSSION}

Based on the results of data analysis through interviews, observation, and documentation, it is found that the city government of Palembang has long been trying to raise awareness of citizens to participation culture [7]. This has been done in various ways including using conventional media, such as print media and modern media, such as social media such as Facebook, twitter, web, and Instagram. Based on the results of interviews with the Head of Public Relations of Palembang City, it is known that various efforts made by the city government of Palembang in raising awareness of Palembang city residents received satisfactory results, the results obtained through the provision of social media as a tool or medium provided by the government of Palembang to capture the aspirations of Palembang city residents. Social media is considered as the most familiar media accessed by Palembang city residents. Based on the results of interviews with the Head of Communications and Information of Palembang City that it was revealed also, if every day there is an increase to the number of users of social media in the city of Palembang. In addition, the results of interviews with some Palembang city residents showed that, they feel comfortable to channel their aspirations through social media. This can be seen in the comments column contained in one of the Instagram of Palembang City Government which is always filled with aspirations of Palembang city residents [8][9]. Whether it is a critique, suggestions and ideas that come from the wishes of every citizen of the city of Palembang. In addition to social media is used as a channel of citizens' aspirations, social media can also serve as a medium that serves as a means of communication in dialectics, meaning the government can be a recipient of information in the form of criticism, suggestions and ideas of ideas, the government can also be a sender of information that aims to notify or socialize an information for all citizens of Palembang city.

\section{REFERENCES}

[1] B. Arianto, "Analisis Penyebab Masyarakat tidak Memilih dalam Pemilu", Jurnal Ilmu Politik dan Ilmu Pemerintahan 1(1) pp 51-60, 2011.

[2] B. Branson, Belajar "Civic Education" dari Amerika (Terjemahan Syarifudin dkk). Yogyakarta: LKIS, 1999.

[3] B. Budiarjo, Partisipasi Politik dan Partai Politik. PT Gramedia Pustaka Utama: Jakarta, 2007.

[4] H. D. Lasswell, Structure and Function of Communication in Society dalam. Wilbur Schramm. (Ed), 2009.

[5] D. Nimmo, Communication Yearbook 4. New Jersey: ICA, 1980.

[6] S.P. Hungtinton and J. Nelson, Partisipasi Politik di Negara perkembang. Jakarta: Rineka Cipta, 1944.

[7] M. McNair, Pengantar Komunikasi Politik. Bandung: Nusamedia, 2016.

[8] S. Karim, Menak Senayan Aristek Komunikasi Politik Indonesia. Bandung: Pustaka Jaya, 2017.

[9] H. Wahyudi, "Peran Kepercayaan politik dan Kepuasan Demokrasi terhadap Partisipasi Politik Mahasiswa", Jurnal Psikologi, Volume 9, pp $2-3,2003$ 